\title{
Effect of fibre and digestible energy levels on growth performance, apparent nutrient digestibility and caecal fermentation of growing rabbits \\ S.O. Osho ${ }^{1}$, A.O. Oso ${ }^{1}$, I.E. Akpan ${ }^{1}$, T.A Ayanniyi ${ }^{1}$, I.M. Ogunade ${ }^{1}$ A.V Jegede, R.A. Sobayo, A.A Adegbenjo and S.O Durosaro ${ }^{2}$ \\ ${ }^{1}$ Department of Animal Nutrition, Federal University of Agriculture, Abeokuta, P.M.B 2240, Abeokuta, Ogun State Nigeria. \\ ${ }^{2}$ Department of Animal Breeding and Genetics, Federal Uni versity of Agriculture, Abeokuta. P.M.B 2240, Abeokuta, Ogun State Nigeria.
}

\begin{abstract}
A seventy-day feeding trial was conducted to investigate the effect of dietary fibre and digestible energy (DE) level on growth performance, apparent nutrient digestibility and caecal fermentation of growing rabbits. The experiment was laid out in a $3 \times 3$ factorial arrangement of 3 levels of fibre (low (249-258 g/kg NDF, $149-157 \mathrm{~g} / \mathrm{kg} \mathrm{ADF}$ ), optimum $(349-381 \mathrm{~g} / \mathrm{kg} \mathrm{NDF}, 188-193 \mathrm{~g} / \mathrm{kg} \mathrm{ADF})$ and high $(430-456 \mathrm{~g} / \mathrm{kg} \mathrm{NDF}, 249-253 \mathrm{~g} / \mathrm{kg}$ ADF)) and 3 levels of DE (low $(8-8.5 \mathrm{MJ} / \mathrm{kg})$, optimum $(10.5-11 \mathrm{MJ} / \mathrm{kg})$ and high $(12-$ $12.30 \mathrm{MJ} / \mathrm{kg})$ ). A total of one hundred and thirty five weaner rabbits were allotted to 9 dietary groups of 15 rabbits each. Main effect of fibre showed that the final live weight and weight gain of rabbits increased $(P<0.01)$ while Ca retention reduced $(P<0.001)$ with increasing dietary fibre level. Rabbits fed $(249-258 \mathrm{~g} / \mathrm{kg} \mathrm{NDF}, 149-157 \mathrm{~g} / \mathrm{kg} \mathrm{ADF})$, had the worst $(P<$ $0.05)$ feed to gain ratio. Rabbits fed $(349-381 \mathrm{~g} / \mathrm{kg} \mathrm{NDF}, 188-193 \mathrm{~g} / \mathrm{kg} A D F)$ had the highest apparent dry matter $(P<0.05)$, ether extract $(P<0.05), N D F(P<0.001), A D F(P<$ $0.001)$ and organic matter digestibility $(P<0.001)$. Main effect of $D E$ showed that rabbits fed high $D E$ recorded the highest $(P<0.05)$ weight gain. Highest $(P<0.01)$ apparent dry matter, crude protein, ash, $N D F, A D F$, organic matter digestibility and Ca retention were recorded with rabbits fed optimum DE diet. Rabbits $(445.70 \mathrm{~g} / \mathrm{kgNDF}, 252.10 \mathrm{~g} / \mathrm{kgADF}$ and $8.01 \mathrm{MJ} / \mathrm{Kg}$ ) recorded the highest $(P<0.001)$ final live weight, weight gain and feed intake $(P<0.05)$ while rabbits fed $(249 \mathrm{~g} / \mathrm{kg} \mathrm{NDF}, 149 \mathrm{~g} / \mathrm{kg} \mathrm{ADF}$ and 8.17MJ/Kg) had the least $(P<0.001)$ final live weight, weight gain, apparent dry matter digestibility, NDF and ADF digestibility. Highest $(P<0.001) N D F$ digestibility was obtained with rabbits fed $(370.79 \mathrm{~g} / \mathrm{kg} \mathrm{NDF}, 189.61$ $\mathrm{g} / \mathrm{kg} \mathrm{ADF}$ and $10.84 \mathrm{MJ} / \mathrm{kg}$ ). Not withstanding the DE level of the diets, rabbits fed with (430$456 \mathrm{~g} / \mathrm{kg} \mathrm{NDF}, 249-253 \mathrm{~g} / \mathrm{kg} \mathrm{ADF}$ ) recorded the highest $(P<0.05)$ total VFA and acetic acid concentration. Rabbits fed $(445.7 \mathrm{~g} / \mathrm{KgNDF}, 250.09 \mathrm{~g} / \mathrm{Kg} A D F$ and $10.52 \mathrm{MJ} / \mathrm{kg})$ recorded the best growth performance, improved caecal fermentation with no adverse effect on apparent nutrient digestibility.
\end{abstract}

Keywords: Growing rabbits; Dietary fibre; Digestible energy; Caecal fermentation

\section{Introduction}

The digestive physiology of rabbits is well adapted to high intake of plant cell wall. Fibre is regarded as one of the main constituent of rabbit feed ranging from 150 $\mathrm{g} / \mathrm{kg}$ to $500 \mathrm{~g} / \mathrm{kg}$ (Gidenne, 2003). A dietary fibre level of $335-400 \mathrm{~g} / \mathrm{kg}$ NDF (De blas and Mateus, 1998; Garcia et al., 1999), 170 $\mathrm{g} / \mathrm{kg}$ ADF (De blas and Mateus, 1998) and a daily intake of $6 \mathrm{~g}$ lignin (Dalle Zotte, 2002) 
were recommended for growing rabbits from previous findings. To formulate a ration that will meet these fibre levels, dietary energy concentration is mostly compromised. This is because diets which are highly fibrous are mostly characterized with low energy concentration (Gidenne et al., 2000). High intake of highly fibrous feeds in rabbit nutrition has been reported to cause reduced feed efficiency (Gidenne et al., 2000) and poor nutrient digestibility (Nicodemus et al., 1999). However, attempts to increase the dietary energy concentration (in most cases at the expense of fibre) resulted in incidence of digestive disturbances (Lebas et al., 1998), loss of appetite and reduced feed conversion efficiency (Bennegadia et al., 2001). A research study aimed at striking an optimal balance between dietary fibre and energy levels is therefore necessary to encourage increased rabbit production especially in developing countries where meat protein from poultry and other livestock are not affordable by the larger populace.

Composition and levels of fibre in previous studies were reported to affect growth (Gutierrez et al., 2002; Tao and Li, 2006), nutrient digestibility (Maitre et al., 1990) and caecal fermentation of rabbits (Garcia et al., 2002). The concentration of caecal volatile fatty acids (VFA) generated in rabbits has been used as a vital tool to estimate the efficiency of nutrient digestibility (Garcia et al., 2000). Although few research have been conducted on the effect of fibre or energy on growth performance of rabbits (Fraga et al., 1983; Maertens et al., 1997; Tao and Li, 2006), studies investigating the combined interaction effect of fibre components (NDF, ADF and ADL) and digestible energy (DE) levels on growth, nutrient digestibility and caecal fermentation of growing rabbits is rare. This study therefore seeks to investigate the effect of fibre and digestible energy on growth performance, nutrient digestibility and caecal fermentation of growing rabbits

\section{Materials and methods \\ Experimental design and dietary treatments}

The study was carried out at the rabbit unit of the Teaching and Research Farm of the University of Agriculture, Abeokuta, Nigeria. The rabbits were kept in a well ventilated building in which the maximum temperature was $30{ }^{\circ} \mathrm{C}$ and the minimum temperature was $27.6{ }^{\circ} \mathrm{C}$. A cycle of $12 \mathrm{~h}$ of light and $12 \mathrm{~h}$ of darkness existed throughout the duration of the trial. Nine experimental diets having three levels of dietary fibre (low (249-258 g/kg NDF, 149 - $157 \mathrm{~g} / \mathrm{kg}$ ADF), optimum $(349-381 \mathrm{~g} / \mathrm{kg}$ NDF, 188 - $193 \mathrm{~g} / \mathrm{kg}$ ADF) and high (430 $456 \mathrm{~g} / \mathrm{kg} \mathrm{NDF}, 249-253 \mathrm{~g} / \mathrm{kg}$ ADF)), and in each case with three DE levels (low $(8-8.5$ $\mathrm{MJ} / \mathrm{kg})$, optimum $(10.5-11 \mathrm{MJ} / \mathrm{kg})$ and high $(12-12.30 \mathrm{MJ} / \mathrm{kg}))$ were formulated for a $3 \times 3$ factorial arrangements (Table 1). Dietary NDF (Pinheiro et al., 2009) and ADF (Gidenne et al., 2004) levels regarded as low fibre in this study were as reported in previous findings. Fibre components (NDF and $\mathrm{ADF}$ ) considered as optimum in this study was as recommended by De blas and Mateous (1998) and Chao and Li (2008). Digestible energy levels of diets similar or close to the recommended value for maximum growth and meat production as reported in previous findings were considered as optimum (INRA, 1989; Lebas, 1991). The diets were offered to the animals in mash form.

Growth response and metabolic trial

A total of one hundred and thirty five, 5 weeks old, weaner rabbits, of mixed breeds with a mean body weight of $448.14 \pm$ $16.05 \mathrm{~g}$ were randomly allotted into 9 
dietary groups of 15 rabbits each. Rabbits were housed individually in cage units (each measuring $405 \mathrm{~mm} \times 510 \mathrm{~mm} \times 320$ $\mathrm{mm}(\mathrm{LWH})$ ) under an intensive housing system from the beginning to the end of the feeding trial which lasted $70 \mathrm{~d}$. A total of 27 similar locally fabricated wired rabbit hutches (each of dimension $202.5 \mathrm{~cm} \times 255$ $\mathrm{cm} \times 32 \mathrm{~cm}(\mathrm{LWH}))$ were used for the study with three hutches assigned to each treatment. Each hutch was partitioned into 5 equal cage units. The hutches were placed in well ventilated building. Feed intake and live weight were recorded per rabbit housed in each cage unit ( $n=15$ per treatment). The total feed intake, weight gain and the feed to gain ratio were also computed.

At the end of the feeding trial, five rabbits per treatment were randomly selected and housed in separate metabolic cages to measure apparent nutrient digestibility. The rabbits were acclimatized for 3 days prior to the commencement of the trial. Selected rabbits were fed with diet at quantity which matched their previous mean daily intake. Sample collection was done for four days. Excreta (free of feed particles and other contaminants) were collected daily from

Table 1 Gross composition of experimental diets $(\mathrm{g} / \mathrm{kg})$

\begin{tabular}{|c|c|c|c|c|c|c|c|c|c|}
\hline \multirow{2}{*}{$\begin{array}{l}\text { Fibre level } \\
\text { Digestible energy level }\end{array}$} & \multicolumn{3}{|l|}{ Low } & \multicolumn{3}{|c|}{ Optimum } & \multicolumn{3}{|l|}{ High } \\
\hline & Low & Optimum & High & Low & $\begin{array}{l}\text { Optim } \\
\text { um }\end{array}$ & High & Low & $\begin{array}{l}\text { Optim } \\
\text { um }\end{array}$ & High \\
\hline Maize & 225 & 190 & 130 & 235 & 195 & 135 & 204 & 164 & 124 \\
\hline Maize starch & 90 & 110 & 145 & 90 & 115 & 140 & 80 & 100 & 120 \\
\hline Vegetable oil & 5 & 20 & 45 & 5 & 20 & 55 & 10 & 30 & 50 \\
\hline wheat offal & 230 & 230 & 230 & 140 & 140 & 140 & 60 & 60 & 60 \\
\hline Rice bran & 90 & 90 & 90 & 130 & 130 & 130 & 195 & 195 & 195 \\
\hline Rice husk & 60 & 60 & 60 & 100 & 100 & 100 & 151 & 151 & 151 \\
\hline $\begin{array}{l}\text { Fixedingredientinclud ing } \\
\text { vitamin/mineral premix }{ }^{a}\end{array}$ & 300 & 300 & 300 & 300 & 300 & 300 & 300 & 300 & 300 \\
\hline \multicolumn{10}{|c|}{ Determined composition (in $\mathrm{g} / \mathrm{kg}$ ) } \\
\hline Dry matter & 901.4 & 910.4 & 901.1 & 909.2 & 899.7 & 908.8 & 906.2 & 900.9 & 899.7 \\
\hline Organic matter & 898.8 & 897.0 & 898.5 & 901.1 & 890.2 & 889.5 & 901.8 & 892.2 & 900.5 \\
\hline Crude ash & 91.20 & 92.50 & 94.50 & 88.90 & 90.40 & 88.80 & 86.20 & 84.20 & 90.60 \\
\hline $\mathrm{NDF}$ & 257.71 & 252.11 & 249.70 & 380.11 & 370.79 & 350.22 & 445.70 & 440.41 & 431.24 \\
\hline $\mathrm{ADF}$ & 157.00 & 154.20 & 149.70 & 192.40 & 189.61 & 188.00 & 252.10 & 250.09 & 249.44 \\
\hline $\mathrm{ADL}$ & 46.67 & 46.10 & 45.82 & 56.40 & 55.91 & 55.34 & 71.90 & 69.71 & 67.82 \\
\hline Gross energy $(\mathrm{MJ} / \mathrm{Kg})$ & 12.03 & 16.09 & 17.62 & 12.67 & 16.95 & 19.13 & 14.19 & 18.56 & 21.29 \\
\hline Digestible energy $^{\mathrm{b}}(\mathrm{MJ} / \mathrm{Kg})$ & 8.17 & 10.97 & 12.11 & 8.06 & 10.84 & 12.27 & 8.01 & 10.52 & 12.09 \\
\hline $\mathrm{Ca}$ & 12.90 & 13.00 & 12.55 & 13.00 & 12.72 & 13.10 & 13.00 & 14.10 & 13.90 \\
\hline $\mathrm{P}$ & 8.10 & 7.99 & 7.55 & 8.00 & 9.55 & 8.95 & 8.20 & 8.00 & 8.11 \\
\hline
\end{tabular}

${ }^{a}$ Contained : $250 \mathrm{~g} / \mathrm{kg}$ soyabean meal (440 g/kg crude protein), $25.0 \mathrm{~g} / \mathrm{kg}$ bone meal, $15.0 \mathrm{~g} / \mathrm{kg}$ oyster shell, 2.0 $\mathrm{g} / \mathrm{kg}$ lysine- HCL, $2.0 \mathrm{~g} / \mathrm{kg}$ DL- methionine, $3.0 \mathrm{~g} / \mathrm{kg}$ salt $(\mathrm{Nacl})$ and $3.0 \mathrm{~g} / \mathrm{kg}$ vitamin $/ \mathrm{mineral}$ premix (providing the following per $\mathrm{kg}$ of diet $0.04 \mathrm{~g}$ manganese, $0.034 \mathrm{~g}$ zinc, $0.023 \mathrm{~g}$ iron, $0.0026 \mathrm{~g}$ copper, $2.48 \mathrm{mg}$ retinol, $0.003 \mathrm{mg}$ cholecalciferol, $5.55 \mathrm{mg}$ riboflavin, $0.70 \mathrm{mg}$ thiamin, $0.70 \mathrm{mg}$ pyridoxine, $2.80 \mathrm{mg}$ niacin, $0.35 \mathrm{mg}$ calcium panto thenate and $0.70 \mathrm{mg}$ cyanacobalamin

${ }^{\mathrm{b}}$ Calculated using de Blas et al., (1992) $(\mathrm{DE}=\mathrm{GE} \times(0.867-0.0012 \mathrm{ADF}))$ 
each cage and dried overnight (at $60{ }^{\circ} \mathrm{C}$ for $12 \mathrm{~h}$ ). Feed samples and ground excreta samples ( $\mathrm{n}=5$ per treatment) were used for chemical analysis. Daily feed intake during the $4 \mathrm{~d}$ collection period was also measured The total tract apparent nutrient digestibility $(\%)$ was estimated as:

$=[(\mathrm{Fi} \times \mathrm{Nf})-((E \times \mathrm{Ne})]) \times 100$ $(\mathrm{Fi} \times \mathrm{Nf})$

Where Fi and $E$ is the quantity of feed intake and excreta output (g DM) during metabolic trial period. The Nf is the nutrient composition in feed while $\mathrm{Ne}$ is the nutrient composition in excreta voided (g DM).

\section{Caecal fermentation}

At the end of $70 \mathrm{~d}$ feeding trial, 5 rabbits were selected at random from each treatment $(n=5$ per treatment $)$ and slaughtered. The caecal content of each rabbit was collected individually for the analysis of $\mathrm{pH}, \mathrm{NH}_{3}-\mathrm{N}$ and VFA. The $\mathrm{pH}$ of the caecal content was determined with a $\mathrm{pH}$ meter equipped with a probe. The caecal contents were centrifuged $(25000 \times g)$ at 0 ${ }^{\circ} \mathrm{C}$ for $10 \mathrm{~min}$. The $\mathrm{NH}_{3}-\mathrm{N}$ and VFA were further measured. For the measurement of $\mathrm{NH}_{3}-\mathrm{N}$ concentration, twenty mililitres of supernate samples were poured into stopped glass flasks, mixed with about 20 $\mathrm{ml}$ of $0.2 \mathrm{M}$ hydrochloric acid, stirred for 30 min. The $\mathrm{NH}_{3}-\mathrm{N}$ concentration was determined spectrophotometrically using the technique of Weatherburn (1967).

For the determination of VFA concentration, a solution of $5 \%$ orthophosphoric acid (v/v) plus $1 \%$ mercury chloride $(\mathrm{w} / \mathrm{v})$ was added to the samples. Volatile fatty acids were measured by gas chromatography, with a gas column: free fatty acids and phenols $10 \% \mathrm{H}_{3} \mathrm{PO} 4$, $1 \%$ acid-washed chromosorb W, $100-120$ mesh. The carrier gas was N2 with a flow rate of $40 \mathrm{ml} / \mathrm{min}: \mathrm{H}_{2}$ and air flows to the detector were $60 \mathrm{ml} / \mathrm{min}$. Injector and detector temperatures were $250{ }^{\circ} \mathrm{C}$ while the oven temperature was $150^{\circ} \mathrm{C}$.

\section{Chemical analysis}

Feed and dried excreta samples were analyzed for proximate constituents according to the Official Methods of Association of Analytical Chemists (A.O.A.C., 1990): ash (method No. 924.05), ether extract (method No. 920.39) and crude protein (total nitrogen $\times 6.25$; method No. 984.13). For the determination of fibre fractions of feed and faecal samples, content of NDF was determined without sodium sulfite and with a heatstable amylase (Van Soest et al., 1991). Acid detergent fibre (ADF) and acid detergent lignin (ADL) were determined by sequential analysis of the residual NDF and not expressed exclusive of residual ash (Van Soest et al.., 1991). The hemicellulose was calculated as the difference between NDF and ADF. The gross energy of the samples was determined using the ballistic bomb calorimeter. Minerals (which mineralsE Should be mentioned) were determined after wet-ashing by concentrated nitric acid and perchloric acid $(1: 1, \mathrm{v} / \mathrm{v})$. Calcium, magnesium and phosphorus content were measured in the ash solution by atomic absorption spectroscopy (Techtron model AA-10) at $422.7,285.2$ and $430 \mathrm{~nm}$, respectively (OJEC, 1973).

Statistical Analysis

Data obtained were laid out in a $3 \times 3$ factorial arrangement of treatments having three dietary fibre (low, $(349-381 \mathrm{~g} / \mathrm{kg}$ NDF, $188-193$ g/kg ADF) and high) and three DE levels (low, optimum and high). Data obtained were analysed using SAS (2003) Software Package. Analysis was done to determine the main effects of fibre levels, digestible energy levels and combined interaction effect of dietary fibre and digestible energy levels. Differences between significant means were separated 
using Duncans Multiple Range Test as outlined by Daniel (1991).

\section{Results}

Growth response and apparent nutrient digestibility

The main effect of dietary fibre and DE level on growth response and apparent nutrient digestibility of the rabbits is shown in Table 2. Final live weight and weight gain increased $(\mathrm{P}<0.01)$ with increasing dietary fibre level. Rabbits fed with $(430-456 \mathrm{~g} / \mathrm{kg}$ NDF, $249-253 \mathrm{~g} / \mathrm{kg}$ ADF) recorded the highest $(\mathrm{P}<0.05)$ feed intake, final liveweight and weight gain. However, rabbits fed with (249-258 g/kg NDF, 149 $157 \mathrm{~g} / \mathrm{kg}$ ADF) had the worst $(\mathrm{P}<0.005)$ feed to gain ratio. Highest apparent dry matter $(\mathrm{P}<0.05)$, ether extract digestibility $(\mathrm{P}<0.05)$, NDF $(\mathrm{P}<0.001)$, ADF $(\mathrm{P}<$ $0.001)$ and organic matter digestibility $(\mathrm{P}<$ $0.001)$ were obtained with rabbits fed diet containing (349 - $381 \mathrm{~g} / \mathrm{kg}$ NDF, 188 - 193 $\mathrm{g} / \mathrm{kg}$ ADF). Ca retention reduced $(\mathrm{P}<$ $0.001)$ with increasing dietary fibre level. The least $(\mathrm{P}<0.001)$ values of NDF, ADF digestibility, calcium and phosphorus retention were obtained with rabbits fed high fibre diets. Main effect of digestible energy level showed highest $(\mathrm{P}<0.05)$ weight gain with rabbits fed with high DE levels. Rabbits fed with low DE recorded the least $(\mathrm{P}<0.001)$ apparent dry matter, NDF, ADF, organic matter digestibility and $\mathrm{Ca}$ retention. Rabbit fed optimum digestible energy diets recorded the highest $(\mathrm{P}<0.001)$ apparent dry matter, ash, ether extract, organic matter, NDF and ADF digestibility, nitrogen and $\mathrm{Ca}$ retention values.

Significant interaction of dietary fibre and DE levels existed for all parameters measured as shown in Table 3. Highest values of final live weight $(\mathrm{P}<0.001)$, weight gain $(\mathrm{P}<0.001)$ and feed intake $(\mathrm{P}<$
$0.05)$ were obtained with rabbits fed with diet containing $\quad(445.70 \mathrm{~g} / \mathrm{KgNDF}$, $250.09 \mathrm{~g} / \mathrm{KgADF}$ and $10.52 \mathrm{MJ} / \mathrm{Kg}$ ). The worst $(\mathrm{P}<0.05)$ feed to gain ratio were obtained with rabbits fed $(257.71 \mathrm{~g} / \mathrm{kg}$ NDF, $157.00 \mathrm{~g} / \mathrm{kg}$ ADF and $8.17 \mathrm{MJ} / \mathrm{kg}$ ) and those fed $(252.21 \mathrm{~g} / \mathrm{kg}$ NDF, 154.20 $\mathrm{g} / \mathrm{kg} \mathrm{ADF}$ and $10.97 \mathrm{MJ} / \mathrm{kg}$ ). Rabbits fed diet containing $(249.70 \mathrm{~g} / \mathrm{kg}$ NDF, $149.70 \mathrm{~g} / \mathrm{kg} \mathrm{ADF}$ and $8.17 \mathrm{MJ} / \mathrm{Kg}$ ) had the least $(\mathrm{P}<0.001)$ final live weight, weight gain, apparent dry matter, NDF and ADF digestibility. Highest $(\mathrm{P}<0.001) \mathrm{NDF}$ digestibility was obtained with rabbits fed diets containing $(370.79 \mathrm{~g} / \mathrm{kg}$ NDF, $189.61 \mathrm{~g} / \mathrm{kg}$ ADFand $10.84 \mathrm{MJ} / \mathrm{Kg}$ ) while highest ADF digestibility recorded with rabbits fed with (431.24 g/kg NDF, 249.44 $\mathrm{g} / \mathrm{kg} \mathrm{ADF}$ and $12.09 \mathrm{MJ} / \mathrm{kg}$ ).

\section{Ceacal Fermentation}

The main effect of dietary fibre and DE level on caecal fermentation of rabbits is as shown in Table 4. The concentration of total VFA and acetic acid increased $(\mathrm{P}<0.05)$ with increasing dietary fibre level. The $\mathrm{P}^{\mathrm{H}}$ level, concentration of $\mathrm{NH}_{3}$ and propionic acid were not affected $(\mathrm{P}>0.05)$ by the main effect of fibre level. Main effect of DE level showed no effect $(\mathrm{P}>0.05)$ on the $\mathrm{P}^{\mathrm{H}}$ level, concentration of $\mathrm{NH}_{3}$, acetic acid, propionic acid and butyric acid concentration. Rabbits fed with $(8-8.5$ $\mathrm{MJ} / \mathrm{kg}$ ) recorded the least $(\mathrm{P}<0.05)$ total volatile fatty acid.

Significant interaction $(\mathrm{P}<0.05)$ of dietary fibre and digestible energy level existed for the concentration of total VFA and acetic acid concentration produced (Table 5). Not withstanding the DE level of the diets, rabbits fed with high fibre diets recorded the highest $(\mathrm{P}<0.05)$ total VFA and acetic acid concentration. 
Effect of fibre and digestible energy levels on growt h perfo rmance of growing rabbits

Table 2: Main effect of dietary fibre and digestible energy levels on growth response and apparent nutrient dig estibility of rabbits

\begin{tabular}{|c|c|c|c|c|c|c|c|c|c|c|}
\hline \multirow[b]{2}{*}{ Parameters } & \multicolumn{5}{|c|}{ Main effect of fibre } & \multicolumn{5}{|c|}{ Main effect of digestible energy } \\
\hline & Low & Optimum & High & SEM & $P$ value & Low & Optimum & High & SEM & $P$ value \\
\hline $\begin{array}{l}\text { Final live weight } \\
\text { ( } \mathrm{g} / \mathrm{r} \text { labbit) }\end{array}$ & $903.93^{\mathrm{c}}$ & $1087.13^{b}$ & $1144.83^{\mathrm{a}}$ & 92.90 & 0.002 & 1053.90 & 1036.00 & 1046.00 & 94.80 & 0.076 \\
\hline Feed Intake (g/rabbit) & $1716.67^{\mathrm{b}}$ & $1691.67^{\mathrm{c}}$ & $1749.90^{\mathrm{a}}$ & 104.55 & 0.035 & $1758.33^{\mathrm{a}}$ & $1661.00^{\mathrm{c}}$ & $1738.90^{\mathrm{b}}$ & 101.66 & 0.043 \\
\hline Weight gain ( $\mathrm{g} / \mathrm{rabbit})$ & $463.77^{\mathrm{c}}$ & $650.00^{\mathrm{b}}$ & $739.37^{\mathrm{a}}$ & 29.11 & 0.004 & $603.30^{\mathrm{b}}$ & $599.97^{\mathrm{b}}$ & $649.87^{\mathrm{a}}$ & 20.44 & 0.044 \\
\hline Feed to gain ratio & $3.70^{\mathrm{a}}$ & $2.60^{\mathrm{b}}$ & $2.37^{\mathrm{b}}$ & 0.36 & 0.042 & 2.91 & 2.77 & 2.68 & 0.12 & 0.220 \\
\hline \multicolumn{11}{|l|}{$\begin{array}{l}\text { Apparent nutrient } \\
\text { digestibility (\%) }\end{array}$} \\
\hline Dry matter & $76.9^{\mathrm{b}}$ & $78.50^{\mathrm{a}}$ & $74.35^{\mathrm{c}}$ & 6.12 & 0.044 & $70.23^{\mathrm{c}}$ & $81.23^{\mathrm{a}}$ & $78.32^{\mathrm{b}}$ & 8.71 & $<0.001$ \\
\hline Ash & $64.83^{\mathrm{a}}$ & $65.70^{\mathrm{a}}$ & $58.66^{\mathrm{b}}$ & 2.96 & 0.032 & $52.95^{\mathrm{c}}$ & $69.81^{\mathrm{a}}$ & $66.42^{\mathrm{b}}$ & 2.55 & $<0.001$ \\
\hline Ether extract & $91.43^{\mathrm{b}}$ & $94.30^{\mathrm{a}}$ & $92.14^{\mathrm{b}}$ & 2.98 & 0.025 & $89.32^{\mathrm{b}}$ & $94.51^{\mathrm{a}}$ & $66.42^{\mathrm{c}}$ & 3.45 & $<0.001$ \\
\hline Nitrogen retention & 81.26 & 81.12 & 80.21 & 1.22 & 0.950 & $78.88^{\mathrm{c}}$ & $82.73^{\mathrm{a}}$ & $80.98^{\mathrm{b}}$ & 1.10 & $<0.001$ \\
\hline NDF & $55.12^{\mathrm{b}}$ & $57.88^{\mathrm{a}}$ & $53.31^{\mathrm{c}}$ & 3.03 & $<0.001$ & $48.96^{\mathrm{c}}$ & $60.36^{\mathrm{a}}$ & $56.99^{\mathrm{b}}$ & 2.99 & $<0.001$ \\
\hline ADF & $44.60^{\mathrm{b}}$ & $46.92^{\mathrm{a}}$ & $41.63^{\mathrm{c}}$ & 2.11 & $<0.001$ & $34.82^{\mathrm{c}}$ & $51.51^{\mathrm{a}}$ & $46.81^{\mathrm{b}}$ & 2.10 & $<0.001$ \\
\hline Organic matter & $75.23^{\mathrm{b}}$ & $79.76^{\mathrm{a}}$ & $76.02^{\mathrm{b}}$ & 3.06 & $<0.001$ & $71.99^{\mathrm{c}}$ & $96.80^{\mathrm{a}}$ & $79.52^{\mathrm{b}}$ & 2.97 & $<0.001$ \\
\hline Calcium retention & $69.00^{\mathrm{a}}$ & $68.33^{\mathrm{b}}$ & $65.67^{\mathrm{c}}$ & 2.98 & $<0.001$ & $62.00^{\mathrm{c}}$ & $71.33 \mathrm{a}$ & $69.67^{\mathrm{b}}$ & 4.46 & $<0.001$ \\
\hline Phosphorus retention & $71.94^{\mathrm{a}}$ & $71.99^{\mathrm{a}}$ & $67.18^{\mathrm{b}}$ & 3.47 & $<0.001$ & 69.02 & 70.97 & 70.91 & 3.39 & 0.950 \\
\hline
\end{tabular}


Os ho, Oso, Akpan, Ayanniyi, Ogunade, Jegede, Sobayo, Adegbenjo and Durosaro

Table 3

Interactive effect of varying dietary fibre and digestible energy on performance characteristics and apparent nutrient digestibility of rabbits

\begin{tabular}{|c|c|c|c|c|c|c|c|c|c|c|c|}
\hline \multirow{2}{*}{$\begin{array}{l}\text { Fibre level } \\
\text { Digestible energy level }\end{array}$} & \multirow[b]{2}{*}{ Low } & \multicolumn{2}{|l|}{ Low } & \multirow[b]{2}{*}{ Low } & \multicolumn{3}{|l|}{ Optimum } & \multicolumn{4}{|l|}{ High } \\
\hline & & Optimum & High & & Optimum & High & Low & Optimum & High & SEM & $P$ value \\
\hline Final weight (g/rabbit) & $811.80^{\mathrm{h}}$ & $850.00^{\mathrm{g}}$ & $1050.00^{\mathrm{e}}$ & $1125.00^{\circ}$ & $1070.70^{z}$ & $1065.70^{\mathrm{d}}$ & $1224.90^{\mathrm{a}}$ & $1187.30^{b}$ & $1022.30^{\mathrm{f}}$ & 90.24 & $<0.001$ \\
\hline Feed Intake (g/rabbit) & $1750.0^{c}$ & $1700.00^{\circ}$ & $1700.00^{\mathrm{e}}$ & $1650.00^{\mathrm{f}}$ & $1700.00^{\circ}$ & $1725.00^{\mathrm{d}}$ & $1875.00^{\mathrm{a}}$ & $1583.00^{\mathrm{g}}$ & $1791.70^{\mathrm{b}}$ & $\begin{array}{l}100.8 \\
7\end{array}$ & 0.025 \\
\hline Weight gain (g/rabbit) & $366.30^{\mathrm{f}}$ & $412.50^{\mathrm{e}}$ & $612.50^{\mathrm{d}}$ & $668.80^{\circ}$ & $668.60^{\circ}$ & $612.60^{\mathrm{d}}$ & $774.80^{\mathrm{a}}$ & $718.80^{\mathrm{b}}$ & $724.50^{\mathrm{b}}$ & 33.51 & $<0.001$ \\
\hline $\begin{array}{l}\text { Feed to gain ratio } \\
\text { Apparent nutrient } \\
\text { digestibility (\%) }\end{array}$ & $4.78^{\mathrm{a}}$ & $4.12^{\mathrm{a}}$ & $2.78^{\mathrm{b}}$ & $2.47^{\mathrm{b}}$ & $2.54^{\mathrm{b}}$ & $2.82^{\mathrm{b}}$ & $2.42^{\mathrm{b}}$ & $2.20^{\mathrm{b}}$ & $2.47^{\mathrm{b}}$ & 0.83 & 0.042 \\
\hline Dry matter & $63.40^{\mathrm{e}}$ & $79.70^{\mathrm{b}}$ & $87.67^{\mathrm{a}}$ & $78.30^{\mathrm{b}}$ & $88.87^{\mathrm{a}}$ & $68.34^{d}$ & $69.00^{\mathrm{d}}$ & $75.11^{\mathrm{c}}$ & $78.95^{\mathrm{b}}$ & 7.22 & $<0.001$ \\
\hline Ash & $44.38^{\mathrm{e}}$ & $68.67^{\mathrm{b}}$ & $81.43^{\mathrm{a}}$ & $65.23^{\mathrm{c}}$ & $81.94^{\mathrm{a}}$ & $49.94^{\mathrm{d}}$ & $49.23^{\mathrm{d}}$ & $38.82^{\mathrm{f}}$ & $67.90^{\mathrm{b}}$ & 4.55 & $<0.001$ \\
\hline Ether extract & $83.67^{\mathrm{f}}$ & $77.88^{\mathrm{g}}$ & $86.62^{\mathrm{e}}$ & $78.44^{\mathrm{g}}$ & $97.22^{\mathrm{a}}$ & $91.25^{\mathrm{c}}$ & $89.85^{\mathrm{d}}$ & $92.36^{\mathrm{C}}$ & $94.22^{\mathrm{b}}$ & 3.77 & $<0.001$ \\
\hline Nitrogen retention & $76.64^{\mathrm{c}}$ & $82.28^{\mathrm{b}}$ & $84.85^{\mathrm{a}}$ & $81.24^{\mathrm{b}}$ & $85.25^{\mathrm{a}}$ & $76.88^{\mathrm{c}}$ & $78.77^{\circ}$ & $80.67^{\mathrm{b}}$ & $81.20^{\mathrm{b}}$ & 4.55 & $<0.001$ \\
\hline NDF & $40.85^{\mathrm{e}}$ & $57.88^{\mathrm{b}}$ & $46.62^{\mathrm{d}}$ & $58.78^{\mathrm{b}}$ & $68.08^{\mathrm{a}}$ & $46.57^{\mathrm{d}}$ & $47.04^{\mathrm{d}}$ & $55.11^{\mathrm{d}}$ & $59.77^{\mathrm{b}}$ & 6.01 & $<0.001$ \\
\hline $\mathrm{ADF}$ & $23.34^{\mathrm{g}}$ & $48.85^{\mathrm{c}}$ & $41.60^{\mathrm{d}}$ & $47.49^{\mathrm{c}}$ & $62.39^{\mathrm{b}}$ & $30.88^{\mathrm{f}}$ & $33.64^{\mathrm{e}}$ & $42.30^{\mathrm{d}}$ & $67.96^{\mathrm{a}}$ & 3.55 & $<0.001$ \\
\hline $\begin{array}{l}\text { Organic matter } \\
\text { digestibility }\end{array}$ & $65.44^{\mathrm{e}}$ & $63.81^{\mathrm{e}}$ & $88.33^{\mathrm{a}}$ & $79.67^{\mathrm{b}}$ & $89.48^{\mathrm{a}}$ & $70.13^{\mathrm{d}}$ & $70.87^{\mathrm{d}}$ & $77.10^{\mathrm{c}}$ & $80.09^{\mathrm{b}}$ & 4.02 & $<0.001$ \\
\hline Calcium retention & $63.00^{\mathrm{d}}$ & $70.00^{\mathrm{b}}$ & $74.00^{\mathrm{a}}$ & $67.00^{\mathrm{c}}$ & $74.00^{\mathrm{a}}$ & $64.00^{\mathrm{d}}$ & $56.00^{\mathrm{e}}$ & $70.00^{\mathrm{b}}$ & $71.00^{\mathrm{b}}$ & 4.99 & $<0.001$ \\
\hline Phosphorus retention & $68.89^{\mathrm{C}}$ & $71.22^{\mathrm{b}}$ & $75.10^{\mathrm{a}}$ & $74.38^{\mathrm{a}}$ & $75.46^{\mathrm{a}}$ & $66.12^{\mathrm{d}}$ & $63.79^{\mathrm{d}}$ & $66.24^{\mathrm{d}}$ & $71.51^{\mathrm{b}}$ & 3.94 & $<0.001$ \\
\hline
\end{tabular}

Table 4: Main effect of varying dietary fibre and digestible energy on caecal fermentation of rabbits

\begin{tabular}{lllllllllll}
\hline \multirow{2}{*}{ Parameters } & \multicolumn{2}{c}{ Main effect of fibre } & \multicolumn{7}{c}{ Main effect of digestible energy } \\
& Low & Optimum & High & SEM & P value & Low & Optimum & High & SEM & P value \\
\hline $\mathrm{P}^{\mathrm{H}}$ & 6.270 & 6.47 & 6.63 & 0.41 & 0.105 & 6.43 & 6.43 & 6.50 & 0.39 & 0.091 \\
$\mathrm{NH}_{3-\mathrm{N}}$ & 2.87 & 2.67 & 2.50 & 0.29 & 0.075 & 2.73 & 2.63 & 2.67 & 0.19 & 0.210 \\
$\begin{array}{l}\text { Caecal VFA } \\
(\mathrm{mmol} / 100 \mathrm{ml})\end{array}$ & & & & & & & & & & \\
Total & $4.53^{\mathrm{c}}$ & $6.33^{\mathrm{b}}$ & $8.17^{\mathrm{a}}$ & 0.97 & 0.022 & $5.80^{\mathrm{b}}$ & $6.60^{\mathrm{a}}$ & $6.63^{\mathrm{a}}$ & 0.78 & 0.044 \\
Acetic & $2.96^{\mathrm{c}}$ & $4.50^{\mathrm{b}}$ & $5.70^{\mathrm{a}}$ & 0.95 & 0.034 & 3.97 & 4.67 & 4.50 & 0.32 & 0.110 \\
Propionic & 0.33 & 0.53 & 0.70 & 0.04 & 0.090 & 0.50 & 0.57 & 0.53 & 0.02 & 0.902 \\
Butyric & 0.73 & 0.96 & 1.13 & 0.01 & 0.092 & 0.83 & 1.07 & 0.93 & 0.04 & 0.140 \\
\hline
\end{tabular}

$\overline{a, b, c}$ Means on the same row with different superscripts are different significantly $(\mathrm{P}<0.05)$ 


\section{Discussion}

Growth response and apparent nutrient digestibility

The highest weight gain and improved feed to gain ratio obtained with rabbits fed diet containing (445.70 g/kg NDF, $252.10 \mathrm{~g} / \mathrm{kg}$ $\mathrm{ADF}$ and $8.01 \mathrm{MJ} / \mathrm{Kg}$ ) agreed with previous findings that rabbits can be sustained on high fibre diets (De Blas et al., 1995; Tao and Li, 2006). Improved growth response were also reported in literature with growing rabbits fed diets containing $233 \mathrm{~g} / \mathrm{kg}$ ADF and $73 \mathrm{~g} / \mathrm{kg}$ ADL (Pinheiro et al., 2009). The result however contradicted the findings of Chao and $\mathrm{Li}$ (2008) who reported a deteriorating poorer feed to gain ratio when rabbits are fed with dietary ADF above $190 \mathrm{~g} / \mathrm{kg}$ level. These differences could be attributed to differences in the nature of dietary ingredients and breeds of rabbits used

Highest feed intake noticed with rabbits fed $(445.70 \mathrm{~g} / \mathrm{kg} \mathrm{NDF}, 252.10 \mathrm{~g} / \mathrm{kg} \mathrm{ADF}$ and $8.01 \mathrm{MJ} / \mathrm{Kg}$ ) diet agreed with the fact that rabbits have the ability to adjust its voluntary intake in response to changes in dietary energy concentration (Macrtens et al., 1988; Patridge et al., 1989). Rabbits fed (430 - $456 \mathrm{~g} / \mathrm{kg} \mathrm{NDF,} 249$ - $253 \mathrm{~g} / \mathrm{kg}$ ADF) diets (characterized mostly with low energy concentration) tend to consume more feed to meet its energy requirement. Similarly, rabbits fed with $(249.70 \mathrm{~g} / \mathrm{kg} \mathrm{NDF}, 149.70$ $\mathrm{g} / \mathrm{kg} \mathrm{ADF}$ and $12.11 \mathrm{MJ} / \mathrm{Kg}$ ) diet resulted in $(249-258 \mathrm{~g} / \mathrm{kg} \mathrm{NDF}, 149-157 \mathrm{~g} / \mathrm{kg}$ ADF) intake (Gidenne, 1997) which could lead to increased incidence of digestive disturbances, enteritis, diarrhea and poor feed conversion efficiency (Lebas et al., 1998; Bennegadia et al., 2001). Compromise in fibre intake has been reported to cause digestive disturbances in the gut of rabbits (De blas, 1992). Although, main effect of DE recorded high weight gain with rabbits offered high DE diets, improved feed conversion ratio were obtained when diet containing combination of $(445.70 \mathrm{~g} / \mathrm{kg}$ NDF, $252.10 \mathrm{~g} / \mathrm{kg}$ ADF and $8.01 \mathrm{MJ} / \mathrm{Kg}$ ) is fed. This was in consistent with Nguyen and Nguyen (2008) who concluded that dietary inclusion of up to $410 \mathrm{~g} / \mathrm{kg}$ NDF in rabbit nutrition gave higher growth rates and better benefits for rabbit producers.

Improved nutrient digestibility and mineral retention obtained with rabbits fed diet containing (370.79 g/ $/ \mathrm{kg}$ NDF, $189.61 \mathrm{~g} / \mathrm{kg}$ ADF and $10.84 \mathrm{MJ} / \mathrm{Kg}$ ) could be due to the fact that dietary fibre (De blas and Mateus, 1998; Garcia et al., 1999; Gidenne et al., 2001) and DE levels (INRA, 1989; Lebas 1991) at this point lied within the recommended level as reported in previous studies. It could also be due to appropriate proportion of cellulose, lignin (low digestible fibre) and hemicellulose (high digestible fibre) which are considered to be adequate in rabbit nutrition (Gidenne and Perez, 2003). The nature (Gidenne et al., 1987; Garcial et al., 1999) and levels of dietary fibre (Gidenne, 2000) were reported to affect nutrient digestibility in rabbits. The degree of lignification (Gidenne and Perez, 1994) and ligocellulose ratio (Gidenne et al., 2001) of the diet containing (370.79 g/ $/ \mathrm{kg} \mathrm{NDF,} 189.61 \mathrm{~g} / \mathrm{kg}$ ADF and $10.84 \mathrm{MJ} / \mathrm{Kg}$ ) diet were also adequate for growing rabbits as reported in previous literatures. This could be contributory to the improved nutrient digestibility obtained with rabbits fed diet containing (370.79 $\mathrm{g} / \mathrm{kg}$ NDF, $189.61 \mathrm{~g} / \mathrm{kg}$ ADF and 10.84 $\mathrm{MJ} / \mathrm{Kg}$ ). The solubility of the dietary fibre components also determines its nutrient digestibility. Inclusion of soluble fibre in pigs delay gastric emptying due to its ability to swell and forms a viscous material (Anderson, 1985), hence improved digestion (Davidson and Mc Donald, 1998) and increased microbial fermentation 
Os ho, Oso, Akpan, Ayanniyi, Ogunade, Jegede, Sobayo, Adegbenjo and Durosaro

Table 5: Interactive effect of varying dietary fibre and digestible energy on caecal fermentation of rabbits

\begin{tabular}{|c|c|c|c|c|c|c|c|c|c|c|c|}
\hline \multirow{2}{*}{$\begin{array}{l}\text { Fibre level } \\
\text { Digestible energy level }\end{array}$} & \multicolumn{3}{|l|}{ Low } & \multicolumn{3}{|c|}{ Optimum } & \multicolumn{5}{|l|}{ High } \\
\hline & Low & Optimum & High & Low & Optimum & High & Low & Optimum & High & SEM & $\begin{array}{l}P \\
\text { value }\end{array}$ \\
\hline $\mathrm{P}^{\mathrm{H}}$ & 6.30 & 6.20 & 6.30 & 6.40 & 6.50 & 6.50 & 6.60 & 6.60 & 6.70 & 0.69 & 0.095 \\
\hline $\begin{array}{l}\mathrm{NH}_{3}-\mathrm{N} \\
(\mathrm{mmol} / 100 \mathrm{ml})\end{array}$ & 2.90 & 2.90 & 2.80 & 2.70 & 2.60 & 2.70 & 2.60 & 2.40 & 2.50 & 0.09 & 0.066 \\
\hline $\begin{array}{l}\text { Caecal VFA } \\
(\mathrm{mmol} / 100 \mathrm{ml})\end{array}$ & & & & & & & & & & & \\
\hline Total & $4.20^{\mathrm{d}}$ & $4.60^{\mathrm{c}}$ & $4.80^{c}$ & $5.00^{c}$ & $6.80^{\mathrm{b}}$ & $7.20^{\mathrm{b}}$ & $8.20^{\mathrm{a}}$ & $8.40^{\mathrm{a}}$ & $7.90^{\mathrm{a}}$ & 0.77 & 0.122 \\
\hline Acetic & $2.70^{\mathrm{c}}$ & $3.20^{\mathrm{c}}$ & $3.00^{c}$ & $3.50^{\mathrm{c}}$ & $4.90^{\mathrm{b}}$ & $5.10^{\mathrm{b}}$ & $5.70^{\mathrm{a}}$ & $5.90^{\mathrm{a}}$ & $5.50^{\mathrm{a}}$ & 0.72 & 0.094 \\
\hline Propionic & 0.30 & 0.40 & 0.40 & 0.50 & 0.50 & 0.60 & 0.70 & 0.80 & 0.60 & 0.09 & 0.059 \\
\hline Butyric & 0.70 & 0.70 & 0.80 & 0.70 & 1.20 & 1.00 & 1.10 & 1.30 & 1.00 & 0.06 & 0.050 \\
\hline
\end{tabular}

${ }_{a, b, c, d}$ Means on the same row with different superscripts are different significantly $(\mathrm{P}<0.05)$ 
(Jorgensen and Jensen, 1994).

Interestingly, the main effect of dietary fibre in this study showed low nutrient digestibility values with rabbits fed (430 $456 \mathrm{~g} / \mathrm{kg}$ NDF, 249 - $253 \mathrm{~g} / \mathrm{kg}$ ADF) diets. Maitre et al. (1990) reported reduced nutrient digestibility when rabbits are fed with increasing level of NDF above the range of $248-323 \mathrm{~g} / \mathrm{kg}$. Literatures confirmed that dietary fraction most related to digestive disturbances in rabbits is insoluble neutral detergent fibre (De Blas et al., 1999; García et al., 2002). Nguyen and Nguyen (2008) also reported reduced dry matter and organic matter digestibility with increasing dietary level of NDF. Excessive intake of dietary fibre decreased gut retention time and increased caecotrophe production due to increasing fibrolytic activity (Perez et al., 1996; Gidenne et al., 1998). In such situation, excessive high intake of fibre could results in a reduction of nutrient digestibility (Deblas et al., 1999).

\section{Caecal fermentation}

The concentration of VFA produced in this study agreed with the proportion of $60-80$ mol of acetate, 8 - 20 mol of butyrate and 3 $10 \mathrm{~mol}$ of propionate per $100 \mathrm{ml}$ of VFA produced as reported by Gidenne (1996). Volatile fatty acids (VFAs) produced as a result of caecal fermentation of digestible fibre (Nicodemus et al., 1999) or undigested nutrients (De blas and Gidenne, 1998) provide a vital source of energy for the rabbits (Bellier and Gidenne, 1996). Rabbits fed with (430 - $456 \mathrm{~g} / \mathrm{kg}$ NDF, 249 $253 \mathrm{~g} / \mathrm{kg}$ ADF) (irrespective of DE level) had increased total VFA and acetic acid concentration. This high total VFA produced by rabbits fed with high fibre resulted from greater quantity of fibre fermentation. The increased acetic acid concentration generated with increasing dietary fibre level agreed with the findings of Chao and $\mathrm{Li}$ (2008). The concentration of total VFA and proportion of acetic acid produced increased with reduction in propionic and butyric acid level as the dietary fibre level is enhanced (Gidenne et al., 2000). Tao and $\mathrm{Li}$ (2006) also confirmed that fibrolytic activities in the caecum of growing rabbits increased as the dietary NDF increased leading to higher production of energy. Increased fibrolytic activities have been reported to improve growth and the health of the rabbits. Peters et al. (1995) found a high VFA levels and a reduced $\mathrm{P}^{\mathrm{H}}$ of the caecal contents in rabbits resulting in a protective effect against experimental enteropathoganc $E$ coli infection.

In conclusion, this study showed that (430 $456 \mathrm{~g} / \mathrm{kg}$ NDF, 249 - $253 \mathrm{~g} / \mathrm{kg}$ ADF) diets in rabbit nutrition improved growth performance, nutrient digestibility and increased caecal fermentation. Rabbits fed diets containing (445.70 g/ $\mathrm{kg}$ NDF, 252.10 $\mathrm{g} / \mathrm{kg} \mathrm{ADF}$ and $8.01 \mathrm{MJ} / \mathrm{Kg}$ ) had the highest weight gain, improved feed to gain ratio and caecal fermentation.

\section{References}

Anderson, J.W., 1985. Physiological and metabolic effect of dietary fibre. Feed Proc. 44, 2902-906

AOAC, 1990. The Official Method of Analysis. Association of Official Analytical Chemists, $5^{\text {th }}$ edition. pp. 68-88. Washington D. C.

Bellier, R., Gidenne, T., 1996. Consequence of reduced fibre intake on digestion, rate of passage and caecal microbial activity in the young rabbit. Br. J. Nutr. 75, 353-363.

Bennegadia, N., Gidenne, T., Licois, D., 2001. Impact of fibre deficiency and sanitary status on non-specific enteropathy of the growing rabbit. Anim. Res. 50, 401-413.

Chao, H.Y., Li, F.C., 2008. Effect of level 
of fibre on performance and digestion traits ingrowing rabbits. Anim. Feed. Sci and Technol. 144, 279-291

Dalle Zotte, A., 2002. Perception of rabbit meat quality and major factors influencingthe rabbit carcass and meat quality. Livest. Prod. Sci. 75, 11-42.

Daniel, W. W., 1991. Biostatistics: A foundation for analysis in the health sciences. $1^{\text {st }}$ edn. New York, J. Willey and Sons.

Davidson, M.H., McDonald, A., 1998. Fibre forms and functions. Nutri. Res. 18, 617-624.

De Blas, C., 1992. The roles of fibre in rabbit nutrition. J. Appl. Rabbit Res. 15, 1329-1343.

De Blas J.C., García J., Carabaño R. 1999. Role of fibre in rabbit diets. Ann. Zootech., 48, 3-13.

De blas.,C., Mateous., G.G., 1998. Feed formulation. In: de Blas, J.C., Wiseman, J. (Eds.), TheNutrition of the Rabbit. CABI International, Wallingford, UK, pp. 241-253.

De Blas, J.C., Taboada, E., Mateos, G.G., Nicodemus, N., Mendez, J., 1995. Effect ofsubstitution of starch for fibre and fat in isoenergetic diets on nutrition digestibility and reproductive performance of rabbits. J. Anim. Sci. $73 ; 1131-1137$.

DeBlas, J.C., Wiseman, M., Fraga, M.J., Villamide, M.J., 1992. Prediction of the digestibleenergy and digestibility of gross energy of feeds for rabbits. Anim. Feed Sci. Technol. 39,

39-59

Fraga, M.J., De blas, J.C., Perez, E., Rodriguez, J.M., Perez, C.J., Galvez, J.F., 1983. Effect of diet on chemical composition of rabbits slaughtered at fixed body weight. J. Anim. Sci. 56, 1097-1104.

Garcia, J., Carabano, R., de Blas, C.,
1999. Effect of fibre source on cell wall digestibility andrate of passage in rabbits. J. Anim. Sci. 77, 898-905.

Garcia, J., Carabano, R., P'erez-Alba, L., de Blas, J.C., 2000. Effect of fibre source on caecalfermentation and nitrogen recycled through cecotrophy in rabbits. J. Anim. Sci. 78, 638

$-646$.

Garcia, J., Gidenne, T., Falc ̃o-eCunha, L., de Blas, C., 2002. Identification of the mainfactors that influence caecal fermentation traits in growing rabbits. Anim. Res. 51, 165173.

Gidenne, T., 1996. Nutritional and ontogenic factors affecting the rabbit caeco-colic digestivephysiology. In: Lebas, F (Ed). Proceedings of the World rabbit congress. INRA. Toulouse, spain pp. 13-28. Incomplete reference... where was the congress heldE

Gidenne, T., 1997. Caeco-colic digestion in the growing rabbit: impact of nutritional factors andrelated disturbances. Livest. Prod. Sci. 51, 73-88.

Gidenne, T., 2000. Alimentação do coelho em crescimento: resultados recentes. In: JornadasInternacionais de Cunicultura. Vila Real, pp. 79-98.

Gidenne, T., 2003. Fibres in rabbit feeding for digestive troubles prevention: respective role of low-digested and digestible fibre. Livest. Prod. Sci. 66, 105-117.

Gidenne, T., Arveux, P., Madec, O., 2001. The effect of the quality of dietary lignocellulose on digestion, zootechnical performance and health of the growing rabbit. Anim. Sci. 73, 97 -104 .

Gidenne, T., Bellier, R., Vaneys, J., 1998. Effect of the dietary fibre origin on the 
digestion and on the caecal fermentation pattern of the growing rabbit. Anim. Sci. 66, 509-517.

Gidenne, T., Mirabito, L., Jehl, N., Perez, J.M., Arveux, P., Bourdillon, A., Briens, C., Duperray, J., Corren, E., 2004. Impact of replacing starch by digestible fibre, at two levels of lignocellulose, on digestion, growth and digestive health of the rabbit. Anim. Sci. 78, 389-398.

Gidenne, T., Perez, J.M., 1994. Apports de lignines et alimentation du lapin en croissance. 1. Cons'equences surla digestion et le transit. Ann. Zootech. 43, 313-322.

Gidenne, T., Pinheiro, V., Falc ao-eCunha, L., 2000. A comprehensive approach of the rabbit digestion: consequences of a reduction in dietary fibre supply. Livest. Prod. Sci. 64, 225 $-237$.

Gidenne, T., Poncet, C., Gomez, L., 1987. Effect de 1 'addition d'un concentr'e riche en fibres dans une ration 'a base de foin, distribu'ee 'a deux niveaux alimentaires chez la lapine adulte. 1. Temps de s'ejour moyen des aliments. Reprod. Nutr. D'ev. 27, 733-743.

Gutierrez, I., Espinosa, A., Gracia, J., Carabano, R., De blas, J.C., 2002. Effect of levels of starch, fibre and lactose on digestion and growth performance of early weaned rabbits. J.Anim. Sci. 80, 1029-1037

INRA, 1989. Alimentation des animaux monogastriques: port, lapin, volailles. $2^{\text {nd }}$ edition, INRA publ., Paris.

Jorgensen, H., Jensen, B.B., 1994. The effect of dietary fibre on digestibility, metabolic activity and microbial gas production in various regions of the gastrointestinal tract of pigs. In: Digestive physiology in pigs. Proceedings of the European
Association of Animal production, Bad Doberan, Germany. pp271

Lebas, F., 1991. Alimentation pratique des lapins en engraissement Cuniculture. 18, 273-281.

Lebas, F., Gidenne, T., Perez, J.M., Licois, D., 1998. Nutrition and pathology. In: De Blas, C., Wiseman, J. (Eds.), The Nutrition of the Rabbit. CABI Publishing, pp. 197-214.

Maertens, L., Bernaerst, D., Deauypere, E., 1988. E fe Lé de la teneur en énergie et du rapport proteins/energié de l' aliment sur les performances d'engraissement et la composition corprelle des lapins de chair. Revue de l’Agric. 41 (5), 1151- 1162.

Maertens, L., Luzi, F., De Groote, G., 1997. Effect of dietary protein and amino acids on the performance, carcass composition and N-excretion of growing rabbits. Ann. Zootech. 46, 255-260.

Maitre, I., Lebas, F., Arveux, P., Bourdillon, A., Duperray, J. and Saint Cast, Y., 1990. Taux de lignocellulose (ADF de Van Soest) et performance de croissance du lapin de chair. 5bme J. Rech. Cunicoles. 12-13 December, Paris. INRA and ITAVI edn. Vol. 2, pp 56.

Nguyen, T.K., Nguyen, T.G., 2008. Effect of different levels of NDF in the diets on feed utilization, growth rate and nutrient digestibility of growing crossbred rabbits. Vietnam. MEKARN Proceedings of Workshop on Organic rabbit production from forages. Cambodia, 22-24 August 2008. Agricultural Publishing House, Hanoi. pp176-182

Nicodemus, N., Caraba no, R., Garc'ıa, J., M'endez, J., De Blas, C., 1999. Performance response of lactating and growing rabbits to dietary lignin 
content. Anim. Feed Sci.Technol. 80, 43-54.

OJEC., 1973. Directive 73/46/EEC of 5 December. Official Journal of the European Communities 30/03/1973. Brussels.

Partridge, G., Ganhawaite P.H., Findlay, M., 1989. Protein and energy retention by growing rabbits offered with increasing proportions of fibre. $J$. Agric. Sci. 112, 171- 178.

Peeters J.E., Maertens, L., Orsenigo, O., Colin, M., 1995. Influence of dietary beet pulp on caecal VFA, experimental colibacillosis and iota-enterotoxaemia in rabbits, Anim. Feed Sci. Technol. 51, 123-139.

Perez, J.M., Gidenne, T., Bouvarel, I., Arveux, P., Bourdillon, A., Briens, C., Le Naour, J., Messager, B., Mirabito, L., 1996. Apports de cellulose dans l'alimentation du lapin en croissance. II. Conséquences sur les performances et la mortalité. Ann. Zootech. 45, 299-309.
Pinheiro, V., Guedes, C.M., OutorMonteiro, D., Mourao, J.L., 2009. Effects of fibre level and dietary mannanoligosaccharides on digestibility, caecal volatile fatty acids and performances of growing rabbits. Anim. Feed Sci. Technol. 148: 288- 300

SAS, 2003. SAS Proprietary Software, SAS Institute, Inc. Release 9.1, Cary, NC.

Tao. Z, Y., Li, F.C., 2006. Effects of dietary neutral detergent fibre (NDF) on production, nutrient utilization, caecum fermentation fibrilytic activity in 2-3months Newzealand Rabbits. $J$. Anim. Nutri Physiol. 90, 467-473.

Van Soest, J.P., Robertson, J.B., Lewis, B.A., 1991. Methods for dietary fibre, neutral detergent fibre and non starch polysaccharides in relation to animal nutrition. J. Dairy Sci. 74, 3583-3594.

Weatherbum, M.W., 1967. Phenolhypochlorite reaction for determination of ammonia. Anal.Chem., 39: 971-974.

Received: $6^{\text {th }}$ A ugust, 2012 Accepted: $10^{\text {th }}$ Ja nuary, 2013 